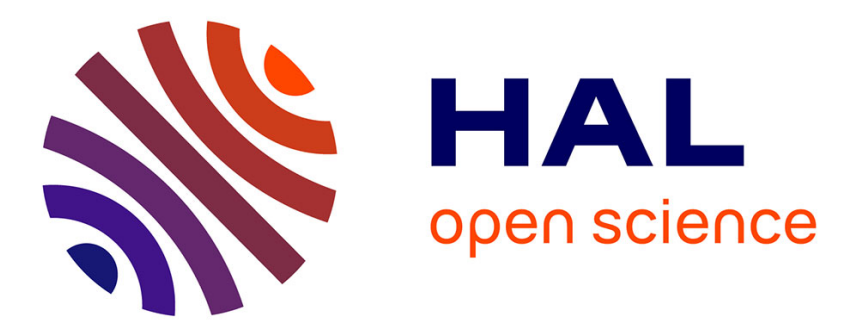

\title{
Behavioural versus physiological photoprotection in epipelic and epipsammic benthic diatoms
}

\author{
Lander Blommaert, Johann Lavaud, Wim Vyverman, Koen Sabbe
}

\section{To cite this version:}

Lander Blommaert, Johann Lavaud, Wim Vyverman, Koen Sabbe. Behavioural versus physiological photoprotection in epipelic and epipsammic benthic diatoms. European Journal of Phycology, 2018, 53 (2), pp.146-155. 10.1080/09670262.2017.1397197 . hal-02326567

\section{HAL Id: hal-02326567 \\ https://hal.science/hal-02326567}

Submitted on 22 Oct 2019

HAL is a multi-disciplinary open access archive for the deposit and dissemination of scientific research documents, whether they are published or not. The documents may come from teaching and research institutions in France or abroad, or from public or private research centers.
L'archive ouverte pluridisciplinaire HAL, est destinée au dépôt et à la diffusion de documents scientifiques de niveau recherche, publiés ou non, émanant des établissements d'enseignement et de recherche français ou étrangers, des laboratoires publics ou privés. 


\section{Behavioural versus physiological photoprotection in epipelic and epipsammic benthic diatoms}

Lander Blommaert ${ }^{\mathrm{a}}$, Johann Lavaud , Wim Vyverman $^{\mathrm{a}}$ \& Koen Sabbe $^{\mathrm{a}}$

${ }^{\mathrm{a}}$ Ghent University, Laboratory of Protistology \& Aquatic Ecology, B-9000 Ghent, Belgium

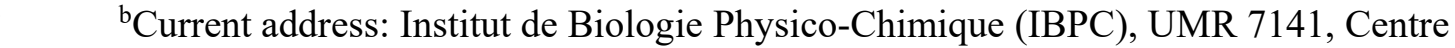

National de la Recherche Scientifique (CNRS), Université Pierre et Marie Curie, 13

Rue Pierre et Marie Curie, F-75005 Paris, France

${ }^{\mathrm{c} C N R S / U n i v e r s i t e ́ ~ L a v a l, ~ U M I 3376 ~ T a k u v i k ~ J o i n t ~ I n t e r n a t i o n a l ~ L a b o r a t o r y, ~}$ Département de Biologie, Pavillon Alexandre Vachon, Université Laval, 1045 avenue de la Médecine, Québec, Qc, G1V 0A6, Canada

* Corresponding author:

Ghent University, Laboratory of Protistology \& Aquatic Ecology, Krijgslaan 281-S8 B9000 Ghent, Belgium, Phone: +32-(0)9-264-85-11, E-mail: Koen.sabbe@ugent.be 


\section{Abstract}

23

Benthic diatoms are dominant primary producers in intertidal marine sediments, which are characterized by widely fluctuating and often extreme light conditions. To cope with sudden increases in light intensity, benthic diatoms display both behavioural and physiological photoprotection mechanisms. Behavioural photoprotection is restricted to raphid pennate diatoms, which possess a raphe system that enables motility and hence positioning in sediment light gradients (e.g. via vertical migration into the sediment). The main physiological photoprotection mechanism is to dissipate excess light energy as heat, measured as Non-Photochemical Quenching (NPQ) of chlorophyll fluorescence. A trade-off between vertical migration and physiological photoprotection (NPQ) in benthic diatoms has been hypothesized before, but this has never been formally tested. We exposed five epipelic diatom species (which move in between sediment particles) and four epipsammic diatom species (which live in close association with individual sand grains) to high light conditions, and characterized both NPQ and the relative magnitude of the migratory response to high light. Our results reveal the absence of a significant downward migratory response in an araphid diatom, but also in several raphid epipsammic diatoms, while all epipelic species showed a significant migratory response upon high light exposure. In all epipsammic species the upregulation of NPQ was rapid and pronounced; NPQ relaxation in low light conditions, however, occurred faster in the araphid diatom, compared to the raphid epipsammic species. In contrast, all epipelic species lacked a strong and flexible NPQ response and showed higher susceptibility to photodamage when not able to migrate. While overall our results support the vertical migration-NPQ trade-off, the lack of strong relationships between the capacity for vertical migration and NPQ within the 
47 epipsammic and epipelic groups suggests that other factors as well, such as cell size,

48 substrate type and photoacclimation, may influence photoprotective strategies.

49

50 Keywords: diatom, microphytobenthos, non-photochemical quenching,

51 photoprotection, trade-off, vertical migration.

52

53 


\section{Introduction}

56 Light is an indispensable but often highly variable resource for microalgae. While traits

57 associated with light utilization are plastic, they can also differ between taxa, often in

58 relation to the specific light climate in their respective habitats (Litchman \& Klausmeier

59 2008). For example, rapid physiological photoprotection mechanisms, such as excess

60 energy dissipation as heat through Non-Photochemical Quenching of chlorophyll

61 fluorescence [NPQ, related to de-epoxidation of xanthophyll pigments in the so-called

62 xanthophyll cycle (XC), (Lavaud \& Goss 2014)] are more strongly developed in diatom

63 species which inhabit strongly mixed and turbid coastal environments than in those

64 inhabiting open ocean environments with a more stable light climate (Lavaud et al.,

65 2007; Dimier et al., 2009; Bailleul et al., 2010).

At low tide, benthic diatoms living in intertidal sediments experience a light

67 climate similar to the terrestrial environment, with often fast and unpredictable

68 fluctuations in light (Lavaud \& Goss 2014), and display a high NPQ capacity (Perkins et al., 2010a). Large differences in NPQ capacity have been observed between benthic growth forms (Jesus et al., 2009, Cartaxana et al., 2011, Barnett et al., 2015, Pniewski

et al., 2015, Cartaxana et al., 2016b). Dense biofilms composed of epipelic diatoms

72 form on fine-grained sediments (Sabbe 1993; Ribeiro et al., 2013). Epipelic diatoms

73 live freely on and in sediments and possess a raphe structure through which mucilage is

74 secreted allowing movement (Round et al., 1990; Aumeier \& Menzel 2012). In addition

75 to endogenous vertical migration rhythms in response to diurnal and tidal cycles

76 (Consalvey et al., 2004), epipelic diatoms can also actively position themselves within

77 sediment light gradients in order to maximize photosynthesis and/or avoid overexposure 
78 (Admiraal 1984; Serôdio et al., 2006; Cartaxana et al., 2016a). While in situ epipelic

79 diatom communities also activate the $\mathrm{XC}$ as a response to high light (Chevalier et al.,

80 2010), downward vertical migration (VM) into the sediment is considered to be their

81 prime response to high light stress (Perkins et al., 2010b). This behavioural response

82 could as such minimize the need for physiological photoprotection (Serôdio et al., 2001;

83 Raven, 2011).

84 In more sandy sediments, epipelic communities are largely replaced by

85 communities of epipsammic diatoms. These diatoms are either araphid (and hence non-

86 motile) and firmly attached to sand grains (either adnate or via a mucilage stalk), or

87 raphid. In the latter case, it is hypothesized that their movement is largely restricted to

88 the sphere of individual sand grains (Sabbe 1997; Ribeiro et al., 2013). As in situ

89 communities living on sandy sediments showed no migratory behaviour and exhibited

90 higher diatoxanthin/diadinoxanthin (Dtx/Ddx) ratios than communities living on silt, a

91 trade-off between behavioural (VM) and physiological photoprotection (NPQ) was

92 proposed (van Leeuwe et al., 2008; Jesus et al., 2009). Exposing both silt- and sand-

93 inhabiting communities to high light in controlled laboratory conditions supported this

94 hypothesis as the sand-inhabiting communities showed higher Dtx/Ddx ratios while not

95 migrating downward in response to high light (Cartaxana et al., 2011). These

96 observations were confirmed by Barnett et al. (2015) who used unialgal cultures to

97 show that epipsammic diatoms indeed have a higher capacity for NPQ and XC than

98 epipelic species. In addition, non-motile epipsammic species show a stronger coupling

99 between NPQ development and the light saturation point $\left(E_{k}\right)$ than motile epipsammic

100 species. Finally, Laviale et al. (2016) showed that in epipelic communities light 
induction of VM occurs at a similar rate as NPQ induction, an essential condition for a migration-physiology trade-off.

While all above studies support a trade-off between NPQ and VM, combined measurements of both traits are limited to natural communities (Perkins et al., 2010b; Serôdio et al., 2012; Laviale et al., 2015, 2016). Natural communities however usually contain a mix of growth forms and species (Hamels et al., 1998), which can hamper the interpretation of NPQ and XC measurements as both growth form and species responses can be quite specific (Underwood et al., 2005; Barnett et al., 2015; Cohn et al., 2015). The photoprotection capacity of raphid and araphid epipsammic growth forms has rarely been investigated in unialgal cultures (Barnett et al., 2015; Blommaert et al., 2017), while the capacity for vertical migration in epipsammic species has to our knowledge never been investigated in cultures.

Here we investigated the relationship between NPQ activation and relaxation and vertical migration capacity for a set of common epipelic (5) and epipsammic (4) diatom species. As it is important that trade-offs are studied with all else being equal (Litchman \& Klausmeier 2008), we quantified both traits under identical conditions, with all strains acclimated to the same light climate. 
123 Epipelic and epipsammic diatom strains were obtained from the diatom culture

124 collection (BCCM/DCG) of the Belgian Coordinated Collection of Micro-organisms

125 (http:/BCCM.belspo.be) and the Nantes Culture Collection-France (NCC),

126 (http://ncc.univ-nantes.fr/). Accession numbers are given in Table 1. Photographs of all

127 species were taken with an Axiophot2 microscope (Carl Zeiss AG, Oberkochen,

128 Germany), equipped with a monochrome digital camera, AxioCam MRm (Carl Zeiss

129 AG, Oberkochen, Germany) (Fig. 1). Species were grown at $20^{\circ} \mathrm{C}$ in batch cultures in a

130 day/night regime of $16 / 8 \mathrm{~h}$ with a light intensity of $20 \mu \mathrm{mol}$ photons $\mathrm{m}^{-2} \mathrm{~s}^{-1}$ using two

131 L58W/840 Lumilux cool white tubes and one L58W/865 cool daylight fluorescent tube

132 (Osram, Munich, Germany). Cells were cultured in Provasoli's enriched f/2 seawater

133 medium using Tropic Marin artificial sea salt (Dr. Beiner GmbH, Wartenberg,

134 Germany) (34.5 $\left.\mathrm{g} \mathrm{l}^{-1}\right)$ enriched with $\mathrm{NaHCO}_{3}\left(80 \mathrm{mg} \mathrm{l}^{-1}\right.$ final concentration). Cultures

135 were acclimated to these culturing conditions for at least 2 weeks prior to the

136 experiments.

\section{Preparation of monospecific biofilms}

138

139

140

141

142

Light brown kaolin (Carl Roth GmbH, Karlsruhe, Germany) was used as a standard test substrate for diatom motility as it has similar properties as mudflat sediment (Hay et al., 1993) and is commercially available. Differences in sediment light climate between natural sediments and kaolin, however, could not be excluded. A schematic overview of artificial biofilm preparation is shown in Fig. 2. 24-well plates were filled with $0.75 \mathrm{~g}$ kaolin in each well and mixed with one ml of medium to obtain a homogenous suspension. The sediment was pelleted by centrifugation at $1000 \mathrm{RCF}$ for $5 \mathrm{~min}$. For 
epipelic diatoms, monospecific suspensions $(0.5 \mathrm{ml}, 6-10 \mu \mathrm{g} \mathrm{Chl} \mathrm{a/ml})$ were mixed with

$1460.1 \mathrm{~g}$ kaolin, pipetted on top of the kaolin within the wells and centrifuged at $50 \mathrm{RCF}$

147 for $1 \mathrm{~min}$. The diatom suspensions were mixed with kaolin because centrifugation

148 without kaolin resulted in an uneven distribution of the diatom layer on the sediment.

149 For epipelic species $10 \mu \mathrm{g} \mathrm{Chl} \mathrm{a/ml} \mathrm{suspensions} \mathrm{were} \mathrm{used,} \mathrm{except} \mathrm{for} \mathrm{both} \mathrm{Navicula}$

150 species (6 $\mu \mathrm{g} \mathrm{Chl} \mathrm{a/ml).} \mathrm{After} \mathrm{a} \mathrm{second} \mathrm{centrifugation} \mathrm{step} \mathrm{(to} \mathrm{conform} \mathrm{with} \mathrm{the}$

151 epipsammic treatment, see below), the supernatant medium was removed and the

152 diatoms were allowed to migrate to the surface for $6 \mathrm{~h}$ in $20 \mu \mathrm{mol}$ photons $\mathrm{m}^{-2} \mathrm{~s}^{-1}$ at

$15320^{\circ} \mathrm{C}$. Higher light intensities were not used for upward migration to avoid a

154 photophobic response or a change in photophysiology. For epipsammic diatoms, $0.1 \mathrm{~g}$

155 kaolin, mixed with $0.5 \mathrm{ml}$ artificial seawater but without diatoms, was first added to the

156 wells already containing $0.75 \mathrm{~g}$ centrifuged kaolin, as described above, and then

157 centrifuged at $50 \mathrm{RCF}$ for $1 \mathrm{~min}$. Afterwards, $1 \mathrm{ml}$ suspension of epipsammic diatoms

$158(2 \mu \mathrm{g} \mathrm{Chl} \mathrm{a} / \mathrm{ml})$ was added and centrifuged at $50 \mathrm{RCF}$ for $1 \mathrm{~min}$ after which the

159 supernatant medium was removed. The epipsammic treatment was slightly different

160 from the epipelic one because the cells were either non-motile or did not migrate to the

161 sediment surface within the same time frame used for the epipelic diatoms. By analogy

162 with the epipelic treatment, the epipsammic species were then placed in $20 \mu \mathrm{mol}$

163 photons $\mathrm{m}^{-2} \mathrm{~s}^{-1}$ at $20^{\circ} \mathrm{C}$ for $6 \mathrm{~h}$ before high light exposure. Surface biomass (expressed

164 as Normalized Difference Vegetation Index (NDVI), see below), measured before the

165 start of the experiments, ranged between 0.1 and 0.25 for all species. To quantify the

166 extent of vertical migration, relative values were calculated, thus standardizing for

167 differences in initial surface biomass.

168 NDVI and chlorophyll fluorescence measurements 
169 Both pulse amplitude modulated (PAM) fluorescence imaging and NDVI were

170 measured with a standard MAXI Imaging PAM M-series (Heinz Walz GmbH,

171 Effeltrich, Germany), equipped with an IMAG-K4 camera and mounted with an IMAG-

$172 \mathrm{MAX} / \mathrm{F}$ filter. The illumination unit of the imaging system contains red $(660 \mathrm{~nm})$ and

173 near-infrared (NIR, $780 \mathrm{~nm}$ ) LEDs, providing monochromatic pulse modulated light.

174 The reflectance images of the monochromatically illuminated samples were captured by

175 the same CCD-chip that captures chlorophyll fluorescence.

In two separate experiments, NPQ and VM (see below) were measured

177 immediately before (0 min) and after 2.5, 5, 10, 15, 20, 25 and 30 min HL illumination

178 (1900 $\mu \mathrm{mol}$ photons $\mathrm{m}^{-2} \mathrm{~s}^{-1}$, photosynthetically available radiation), provided by the

179 MAXI Imaging PAM Blue LED-panel. The outer wells of the 24-well plates were not

180 included to avoid inhomogeneity in light intensity.

181 The intensities of both red and NIR illumination sources were calibrated with a

$18218 \%$ grey standard (Neutral Grey Card 4963, FOTOWAND-Technic Dietmar Meisel,

183 Sudwalde, Germany), placed in the middle of the camera field of view as during HL

184 exposure the NIR reflectance decreased while red reflectance increased. Red and NIR

185 reflectance images were captured automatically using the script function in the

186 ImagingWin software. Areas of interest (AOI) were placed in the middle of each well to

187 avoid edge-effects using the ImagingWin (v2.41a) software (Heinz Walz GmbH,

188 Effeltrich, Germany). Sediment temperature was maintained at $20^{\circ} \mathrm{C}$ by working in an

189 air-conditioned room, removing the Perspex eye-protection hood and providing

190 additional cooling by a fan, and keeping the 24-well plate, which was perforated in

191 between the wells, in a water bath on a stirring plate. 

of each HL interval to create a new file in which only one red and NIR image could be saved. Red and NIR were captured after $10 \mathrm{~s}$ of darkness after this saturating pulse to avoid interference. NDVI was calculated as (R780 - R660)/(R780 + R660) using the AOI averages (Rouse et al., 1974). An NDVI vs. chlorophyll $a(\mathrm{Chl} a)$ calibration curve was constructed by creating artificial biofilms by centrifuging (cf. epipsammic treatment above) suspensions of known Chl $a$ content (determined spectrophotometrically, Jeffrey \& Humphrey, 1975) of the diatom Phaeodactylum tricornutum K. Bohlin (Fig. 3). The extent of vertical migration was calculated as the relative (percentage) decline in initial NDVI values (Laviale et al., 2016) after subtraction of the NDVI value of kaolin without diatoms, which was recorded simultaneously. Even though we controlled for changes in red and NIR illumination, we observed a decline in recorded NDVI of a sheet of green paper (absorbing in the red spectrum) under the same light conditions, possibly due to a shift in LED-spectrum resulting from the heating up of the LED panel during HL illumination. We corrected

207 for this artifact (see Supplemental Fig. S1) by adding the average decline of 15 observations ( 3 independent measurements of 5 AIOs in the green sheet) to the recorded data for diatoms. assay. As no sediment was present, a behavioural photoprotection response was not possible. NPQ reversal was measured during an additional 30 min low light (LL) 214 recovery period $\left(15 \mu \mathrm{mol}\right.$ photons $\left.\mathrm{m}^{-2} \mathrm{~s}^{-1}\right)$. Saturating pulses $(0.8 \mathrm{~s}$, INT 8$)$ were fired automatically each 5 min. A fluorescence standard (Heinz Walz GmbH, Effeltrich, 
216 Germany) was measured simultaneously to correct for deviations in measuring light 217 intensity during HL. NPQ was calculated as $\left(\mathrm{F}_{\mathrm{m}}-\mathrm{F}_{\mathrm{m}}{ }^{\prime}\right) / \mathrm{F}_{\mathrm{m}}$ ', where $\mathrm{F}_{\mathrm{m}}$ is the Maximum 218 PSII chlorophyll fluorescence yield and $\mathrm{Fm}_{\mathrm{m}}$ ' is maximum PSII Chl fluorescence yield $219\left(\mathrm{~F}_{\mathrm{m}}\right)$ during illumination. As $\mathrm{F}_{\mathrm{m}}$ ' values recorded during HL were lower than the 220 minimum PSII Chl fluorescence yield $\mathrm{F}_{0}$ (as observed in diatoms by Lavaud et al., 221 2002), qN (as used by Laviale et al., 2016) was not determined. Photosynthetic 222 efficiency of PSII $\left(\Delta \mathrm{F} / \mathrm{Fm}_{\mathrm{m}}{ }^{\prime}\right)$ was calculated as $\left(\mathrm{Fm}_{\mathrm{m}}{ }^{\prime}-\mathrm{F}^{\prime}\right) / \mathrm{F}_{\mathrm{m}}{ }^{\prime}$ and expressed as a 223 percentage, taking the maximal photosynthetic efficiency $\left(\mathrm{F}_{\mathrm{v}} / \mathrm{F}_{\mathrm{m}}\right)$, measured 224 immediately before HL onset as 100\%. replicates per species) were compared between species using ANOVA, followed by a exponential decay function (nonlinear regression), derived from Olaizola \& Yamamoto (1994):

(1) NPQ(t) $=\mathrm{NPQ}_{\max }+\left[\mathrm{NPQ}_{0}-\mathrm{NPQ} \mathrm{max}_{\max }\right] \mathrm{e}^{-\mathrm{kt}}$ where $t$ represents time during HL and NPQmax and NPQ 0 represent NPQ after $30 \mathrm{~min}$ HL and before HL onset, respectively.

(2) $N P Q(t)=N P Q_{r}+\left[N P Q_{\max }-N P Q_{r}\right] e^{-k t}$ where $t$ represents time during recovery and $\mathrm{NPQ}_{\max }$ and $\mathrm{NPQ}_{\mathrm{r}}$ represent NPQ at the start of the recovery period and after 30 min of recovery in LL, respectively. Statistical analyses were conducted using the statistical software package SAS 9.4 (SAS Institute Inc., Cary, NC, USA). Exponential decay functions were fitted using the nonlinear regression procedure (PROC NLIN). Measured and fitted parameters (3 biological Tukey's test, using the General Linear Model procedure (PROC GLM). P-values of 
2400.05 or less were considered statistically significant. A decrease in surface biomass

241 was evaluated as a one-sided t-test (only a decrease was considered). 


\section{Results}

244 NDVI measured with the MAXI Imaging PAM M-series

245 A dilution series of Phaeodactylum tricornutum suspensions of known Chl $a$ content

246 was centrifuged on kaolin sediment to create artificial biofilms. NDVI of these biofilms

247 correlated very well $\left(\mathrm{R}^{2}=0.98, p<0.0001\right)$ with Chl $a$ content (Fig 3). As the y-intercept

248 was larger than zero $(p=0.0002)$, a blank with bare sediment was included and its

249 NDVI measurement subtracted from all samples in all VM experiments.

\section{Behavioural photoprotection - vertical migration (VM)}

251 All epipelic species showed a significant (one-sided t-test, $p<0.05$ ) decrease in surface

252 biomass (20-40\%) by the end of the HL illumination period (VM $\left.\mathrm{VM}_{30}\right)$ (Fig. 4a, b;

253 significant $p$-values listed in Table S1). As only two replicates were included for

254 Entomoneis paludosa, this species was excluded from statistical analysis. None of the

255 epipsammic species, including the motile ones, showed a significant surface biomass

256 decline during the HL period (Fig. 4a, b; p-values listed in Table S1). Of the epipelic

257 species, only Craspedostauros britannicus showed a small but significant decrease in

258 surface biomass after $2.5 \mathrm{~min}(p=0.001)$. After $15 \mathrm{~min}$ of HL, C. britannicus, Navicula

259 phyllepta and N. arenaria had significantly lower surface biomass than at the start of the

260 experiment (one-sided t-test). The smallest epipelic species $N$. phyllepta exhibited the

261 most pronounced vertical migration (Fig. 4a); decreasing its surface biomass

262 significantly more than any other tested epipelic species within the 30 min HL exposure

263 period (ANOVA and Tukey's post hoc pairwise comparison, $p$-values reported in Table

264 S2). No significant differences in surface biomass decrease were found between the 
other epipelic diatoms after 30 min of HL (Table S2). A control experiment, using only the largest (N. arenaria) and smallest ( $N$. phyllepta) epipelic diatoms ( 2 technical replicates each), showed no VM in growth light conditions $\left(20 \mu \mathrm{mol}\right.$ photons $\mathrm{m}^{-2} \mathrm{~s}^{-1}$, Supplemental Fig. S2).

\section{Physiological photoprotection - NPQ}

All investigated epipsammic species displayed a strong NPQ induction, resulting in significantly higher NPQ values than epipelic species after 5 min HL (Fig. 4c, d) (ANOVA and Tukey's post hoc pairwise comparison, $p$-values reported in Table S3). No significant differences in NPQ were observed between diatoms of the same growth form at this time point (Table S3). The NPQ induction rate was lowest in C. britannicus (rate constant $\mathrm{k}=0.08 \mathrm{~min}^{-1} ; \mathrm{SD}=0.02$ ), which was significantly lower than in $B$. lucens, E. paludosa, O. guenter-grassii and P. delicatulum (ANOVA and Tukey's post hoc pairwise comparison, $p$-values reported in Table S4). The epipsammic species showed a comparable but lower further increase in NPQ during the rest of the HL period. In the epipelic species, NPQ diverged by the end of the HL exposure period. Both C. britannicus and E. paludosa showed a strong NPQ increase during the HL period, resulting in significantly higher NPQ values than the other tested epipelic species (except for the difference between E. paludosa and N. phyllepta which was not significant, ANOVA and Tukey's post hoc pairwise comparison, $p$-values reported in Table S5).

During the 30 min low light recovery period NPQ relaxed rapidly in all epipsammic species, whereas only one epipelic species, $N$. arenaria, showed clear NPQ relaxation. Sustained quenching (NPQs) after 30 min recovery was highest for $C$. 
britannicus, followed by E. paludosa. Fitting NPQ relaxation with exponential decay

289 functions revealed significantly faster NPQ relaxation in the araphid epipsammic diatom

290 Opephora guenter-grassii (rate constant $\mathrm{k}=0.52 \mathrm{~min}^{-1} ; \mathrm{SD}=0.03$ ), whereas no

291 significant differences were observed between the raphid epipsammic diatoms and $N$.

292 arenaria (rate constant $\mathrm{k}=0.13 \mathrm{~min}^{-1} ; \mathrm{SD}=0.06$ ) (ANOVA and Tukey's post hoc

293 pairwise comparison, $p$-values reported in Table S4). The recovery of the quantum yield

294 of PSII ( $\Delta \mathrm{F} / \mathrm{Fm}_{\mathrm{m}}$ ') after $30 \mathrm{~min}$ of LL (Fig. 5) was higher in all epipsammic species

295 compared to the investigated epipelic species, with the notable exception of the epipelic

296 species $N$. arenaria which showed an equally high recovery (ANOVA and Tukey's post

297 hoc pairwise comparison, $p$-values reported in Table S6).

Plotting the NPQ values after 5 min HL versus VM VM $_{30}(\%$ NDVI decrease after 30

min) (Fig. 6) revealed a clear VM-NPQ trade-off between the epipelic and epipsammic

300 diatom groups, with epipelic diatoms displaying high $\mathrm{VM}_{30}$ and low NPQ, and

301 epipsammic diatoms showing no clear VM and high NPQ. No VM30/NPQ trade-offs,

302 however, were observed within both functional groups. 
304 Discussion

305

As the ability to vertically migrate (VM) away from high light to avoid photoinhibition

307 might minimize the costs associated with high and flexible NPQ (Raven, 2011), we compared NPQ and VM capacity as photoprotection mechanisms in a set of five epipelic and four epipsammic species and confirm a general NPQ-VM trade-off between both functional groups.

The fact that no vertical movement was observed in the epipsammic species 
have no data for the first five minutes of high light, during which most of the NPQ induction, due to Ddx de-epoxidation, takes place (Serôdio et al., 2005).

Besides a strong NPQ after HL onset, epipsammic diatoms were also able to relax NPQ rapidly during low light conditions. Within both growth forms, trade-offs between both photoprotective strategies were not observed. However, the only araphid (and hence by definition non-motile) epipsammic diatom included here showed considerably faster relaxation of NPQ after high light exposure than the raphid epipsammic diatoms and is therefore able to more efficiently track rapid changes in irradiance intensity (Lavaud et al., 2007; Lavaud \& Lepetit 2013). Taken together, our results confirm that epipelic and epipsammic growth forms can be seen as different functional groups exhibiting contrasting primary photoprotection strategies.

NPQ differences between epipelic and epipsammic growth forms were studied by Barnett et al. (2015), and agree with our observations after 5 min HL. Higher NPQ values in epipsammic diatoms were attributed to higher Dtx production, originating from a larger Ddx + Dtx pool rather than a higher Ddx de-epoxidation state. The measured NPQ values in two epipelic species (C. britannicus and E. paludosa), however, increased to similar levels as in the epipsammic diatoms after 30 min HL, a feature not observed by Barnett et al. (2015) as only 5 min illumination periods were used. During the low light recovery period, however, all epipelic species except $N$. arenaria showed high NPQs and a low recovery of PSII quantum yield. High NPQs has been observed after exposure to high light conditions or a combination of high light and elevated temperatures (Zhu et al., 2010; Lavaud \& Lepetit 2013; Laviale et al., 2015), and has been attributed to a slow epoxidation of Dtx back to Ddx (Lavaud \& Lepetit 2013; Lavaud \& Goss 2014; Blommaert et al., 2017) and/or photoinhibition (qI). In 
contrast with our observations, epipelic communities freshly obtained from the field are able to withstand high light doses (up to $1200 \mu \mathrm{mol}$ photons $\mathrm{m}^{-2} \mathrm{~s}^{-1}$ ) for up to three hours, even when VM is inhibited (Serôdio et al., 2012; Laviale et al., 2015). Moreover, they show higher NPQ values, while relaxing their NPQ more in low light conditions (Serôdio et al., 2005, 2008, 2012), suggesting that these field communities are less sensitive to photoinhibition than monospecific epipelic cultures. This could be due to the fact that the diatom cultures used in our study were acclimated to rather low light intensities $\left(20 \mu \mathrm{mol}\right.$ photons $\left.\mathrm{m}^{-2} \mathrm{~s}^{-1}\right)$ and exposed to relatively high light intensities. Acclimation to higher irradiances increased the NPQ capacity of epipelic diatoms (Cruz \& Serôdio 2008; Ezequiel et al., 2015; Barnett et al., 2015) and caused them to accumulate at higher light intensities in a light gradient (Ezequiel et al., 2015). As a result, the VM/NPQ trade-off between epipsammic and epipelic diatoms observed in the field may not be as pronounced as observed in our experiments.

Alternatively, the high NPQs/qI in epipelic species, as observed in this study, could be related by the origin of the strains. Diatom communities originating from Portuguese mudflats, as used in the above studies, tend to have overall higher NPQ and less NPQs and/or photoinhibition after high light exposure than communities sampled at higher latitudes along the Atlantic Coast (Laviale et al., 2015). Pniewski et al. (2015) also observed photoinhibition (measured as a decline in oxygen evolution-irradiance curves) in epipelic communities from Aiguillon Bay (Atlantic coast, France). The observed absence or low amount of NPQs/qI and in general higher recovery of PSII quantum yield in epipsammic diatoms in this study confirms that the energy dissipating mechanisms of these diatoms are capable of tracking light fluctuations (cf. Blommaert et al., 2017) and optimizing photosynthesis in rapidly fluctuating and high light 
conditions, as photosynthesis can be forgone if energy dissipating mechanisms fail to relax in light-limiting conditions (Raven, 2011). Finally, sustained NPQ in MPB diatoms may be advantageous to keep the antenna system in a basal dissipative state, allowing the cells to cope with a sudden increase in light intensity after a long dark period as may happen during immersion and night emersion (Lavaud \& Goss 2014). Differences in motility of epipelic diatoms (here mainly between N. phyllepta and larger species) were not reflected in NPQ capacity and thus do not point to a VMNPQ trade-off within the epipelic group. N. phyllepta is much smaller ( 13 $\mu \mathrm{m}$ long) than the other studied epipelic species ( $>30 \mu \mathrm{m}$ long) but exhibited the strongest migratory response, whereas no differences in VM were observed between the larger species. The difference in VM between $N$. phyllepta and the larger species may be due to the fact that because of its smaller size (and assuming comparable pigment concentration per unit biovolume) pigment self-shading may be lower, rendering the cells more vulnerable to photoinactivation (Key et al., 2010) and therefore requiring higher photoprotection (i.c. VM). In this respect it is interesting to note that in a field study small naviculoid diatoms were mainly observed at the sediment surface in early morning when light intensity was still relatively low whereas larger species dominated the intertidal surface biofilm at noon (Underwood et al., 2005). It should also be noted that while VM was observed in all epipelic species, most diatom biomass stayed at the sediment surface as observed by Laviale et al. $(2015,2016)$. Therefore, epipelic diatoms might have used alternative photoprotection strategies or displayed within-population cyclical micromigration at the sediment surface (Kromkamp et al., 1998), as such obscuring differences in VM as a photoprotection strategy. 
399 An NPQ-VM capacity trade-off was also not observed within the epipsammic group: no 400 significant NPQ differences were detected during the high light period and no 401 significant VM was observed. However, all epipsammic species we tested, with the 402 exception of $O$. guenter-grasssii, were raphid and therefore in principle capable of 403 movement. However, despite the fact that some of them were in the same size range 404 (see Fig. 1) as N. phyllepta (which displayed the strongest migratory response), they did 405 not migrate down in response to high light. The absence of vertical migration is in 406 accordance with the lack of endogenous migratory rhythms in epipsammic communities 407 (Jesus et al., 2009) and the observation that epipsammic diatoms in the field do not seem to migrate down in response to high light (Cartaxana et al., 2011). Barnett et al.

409 (2015) did observe differences in NPQ capacity between motile and non-motile

410 epipsammic species but not at the highest light intensity $\left(2000 \mu \mathrm{mol}\right.$ photons $\left.\mathrm{m}^{-2} \mathrm{~s}^{-1}\right)$.

411 The most notable difference between the epipsammic species in our study was the faster 412 NPQ relaxation in the araphid species O. guenter-grassii, which is due to fast Dtx 413 epoxidation in low light conditions (Blommaert et al., 2017). The slower relaxation in 414 raphid epipsammic species may suggest that they do use motility, not to perform VM 415 but to move to slightly more shaded areas on the sand grain surface, such as 416 depressions, where epipsammic diatoms are often seen to aggregate (Miller et al., 1987; 417 Jewson et al., 2006; Sabbe, unpubl. obs.). While it has been hypothesized that cell 418 accumulations in depressions can represent a strategy to protect against abrasion (Miller 419 et al., 1987), it could also be a way to reduce high light stress through increased cell 420 shading caused by cell accumulation and the microtopography of the sand grains. This 421 may slightly reduce the need for the very rapid NPQ relaxation observed in the araphid 422 species. An alternative explanation for the absence of significant VM in raphid 
423 epipsammic species in sandy sediments is that because light is scattered and penetrates 424 deeper than in silty sediments (Kühl et al., 1994; Cartaxana et al., 2016b), downward

425 VM would probably not drastically change the experienced light climate (Cartaxana et 426 al., 2016b). A third potential explanation for the observed difference in NPQ relaxation

427 between the araphid and raphid epipsammic species could be that slower NPQ

428 relaxation represents a phylogenetic signal typical for raphid, motile diatoms which was

429 retained in raphid taxa which adopted an epipsammic growth form.

Finally, it needs to be pointed out that the distinction between araphid and raphid

431 epipsammon does not necessarily coincide with a difference in motility. Some raphid

432 species, such as Biremis lucens are usually observed as small colonies which are

433 attached to the sand grain surface via their girdle side (Sabbe et al., 1995). For this

434 reason, this species was classified as non-motile in Barnett et al., (2015). In the present

435 study, we focused on the distinction between araphid and raphid, as raphid diatoms are

436 at least potentially motile as they possess a raphe. Motility in most of these forms,

437 however, has not yet been properly characterized.

\section{Acknowledgements}

440 The authors would like to thank the Research Foundation Flanders (FWO project

441 G.0222.09N), Ghent University (BOF-GOA 01G01911) and the Egide/Campus France-

442 PHC Tournesol (n128992UA) exchange program for their financial support. JL also

443 thanks the CNRS for their financial support. 


\section{References}

447 Admiraal, W. (1984). The ecology of estuarine sediment-inhabiting diatoms. Progress

$448 \quad$ in Phycological Research, 3: 269-322.

449

Aumeier, C. \& Menzel, D. (2012). Secretion in the Diatoms. In Secretions and Exudates in Biological Systems, (Vivanco, J.M. \& Baluška, F., editors), 221-250. Springer, Berlin Heidelberg.

Bailleul, B., Rogato, A., De Martino, A., Coesel, S., Cardol, P., Bowler, C., Falciatore, A. \& Finazzi, G. (2010). An atypical member of the light-harvesting complex stress-related protein family modulates diatom responses to light. Proceedings of the National Academy of Sciences, 107: 18214-18219.

Barnett, A., Méléder, V., Blommaert, L., Lepetit, B., Gaudin, P., Vyverman, W., Sabbe, K., Dupuy, C. \& Lavaud, J. (2015). Growth form defines physiological photoprotective capacity in intertidal benthic diatoms. The ISME Journal, 9: 3245.

Blommaert, L., Huysman, M.J.J., Vyverman, W., Lavaud, J. \& Sabbe, K. (2017). Contrasting NPQ dynamics and xanthophyll cycling in a motile and a non motile intertidal benthic diatom. Limnology and Oceanography, doi:10.1002/1no.10511

Cartaxana, P., Cruz, S., Gameiro, C. \& Kühl, M. (2016a). Regulation of intertidal microphytobenthos photosynthesis over a diel emersion period is strongly affected by diatom migration patterns. Frontiers in Microbiology, 7: 872.

Cartaxana, P., Ribeiro, L., Goessling, J., Cruz, S. \& Kühl., M. (2016b). Light and $\mathrm{O}_{2}$ microenvironments in two contrasting diatom-dominated coastal sediments. 
Cartaxana, P., Ruivo, M., Hubas, C., Davidson, I., Serôdio, J. \& Jesus, B. (2011).

Physiological versus behavioral photoprotection in intertidal epipelic and epipsammic benthic diatom communities. Journal of Experimental Marine Biology and Ecology, 405: 120-127.

Chevalier, E.M., Gévaert, F. \& Créach, A. (2010). In situ photosynthetic activity and xanthophylls cycle development of undisturbed microphytobenthos in an intertidal mudflat. Journal of Experimental Marine Biology and Ecology, 385: 44-49.

Cohn, S.A., Halpin, D., Hawley, N., Ismail, A., Kaplan, Z., Kordez, T., Kuhn, J., Macke, W., Marhaver, K., Ness, B., Olszewski, S., Rice, E., Sbarboro, J., Wolske, A. \& Zapata, Y. (2015). Comparative analysis of light-stimulated motility responses in three diatom species. Diatom Research, 30: 213-225.

Consalvey, M., Paterson, D.M. \& Underwood, G.J.C. (2004). The ups and downs of life in a benthic biofilm: Migration of benthic diatoms. Diatom Research, 19: 181-202

Cruz, S. \& Serôdio, J. (2008). Relationship of rapid light curves of variable fluorescence to photoacclimation and non-photochemical quenching in a benthic diatom. Aquatic Botany, 88: 256-264.

Dimier, C., Giovanni, S., Ferdinando, T. \& Brunet, C. (2009). Comparative ecophysiology of the xanthophyll cycle in six marine phytoplanktonic species. Protist, 160: 397-411.

Ezequiel, J., Laviale, M., Frankenbach, S., Cartaxana, P. \& Serôdio, J. (2015).

Photoacclimation state determines the photobehaviour of motile microalgae: The 
case of a benthic diatom. Journal of Experimental Marine Biology and Ecology, 468: 11-20.

Hamels, I., Sabbe, K., Muylaert, K., Barranguet, C., Lucas, C., Herman, P. \& Vyverman, W. (1998). Organisation of microbenthic communities in intertidal Estuarine flats, a case study from the molenplaat (Westerschelde estuary, The Netherlands). European Journal of Protistology, 34: 308-320.

Hay, S.I., Maitland, T.C. \& Paterson, D.M. (1993). The speed of diatom migrationthrough natural and artificial substrata. Diatom Research, 8: 371-384.

Jeffrey, S.W. \& Humphrey, G.S. (1975). New spectrophotometric equations for determining chlorophylls $a, b, c 1$ and $c 2$ in higher plants, algae and natural phytoplankton. Biochemie und Physiology der Pflanzen, 167: 191-194.

Jesus, B., Brotas, V., Ribeiro, L., Mendes, C.R., Cartaxana, P. \& Paterson, D.M. (2009). Adaptations of microphytobenthos assemblages to sediment type and tidal position. Continental Shelf Research, 29: 1624-1634.

Jewson, D.H., Lowry, S.F. \& Bowen, R. (2006). Co-existence and survival of diatoms on sand grains. European Journal of Phycology, 41: 131-146.

Key, T., McCarthy, A., Campbell, D.A., Six, C., Roy, S. \& Finkel, Z.V. (2010). Cell size trade-offs govern light exploitation strategies in marine phytoplankton. Environmental Microbiology, 12: 95-104.

Kromkamp, J.C., Barranguet, C. \& Peene, J. (1998). Determination of microphytobenthos PSII quantum efficiency and photosynthetic activity by means of variable chlorophyll fluorescence. Marine Ecology Progress Series, 162: 45-55. 
512 Kühl, M., Lassen, C. \& Jorgensen, B.B. (1994). Light penetration and light intensity in 513 sandy marine sediments measured with irradiance and scalar irradiance fiber-optic $514 \quad$ microprobes. Marine Ecology Progress Series, 105: 139-148.

515 Lavaud, J., \& Goss, R. (2014). The peculiar features of the non-photochemical 516 fluorescence quenching in diatoms and brown algae. In Non-Photochemical 517 Quenching and Energy Dissipation in Plants, Algae and Cyanobacteria (Demmig518 Adams, B., Garab, G., Adams III, W. \& Govindjee, editors), 421-443. Springer, $519 \quad$ Netherlands.

520

521

522

523

524

525

526

527

528

529

530

531

532

533

Lavaud, J., \& Lepetit, B. (2013). An explanation for the inter-species variability of the photoprotective non-photochemical chlorophyll fluorescence quenching in diatoms. Biochimica et Biophysica Acta, 1827: 294-302.

Lavaud, J., Rousseau, B., Van Gorkom, H. J. \& Etienne, A. (2002). Influence of the diadinoxanthin pool size on photoprotection in the marine planktonic diatom Phaeodactylum tricornutum. Plant Physiology, 129: 1398-1406.

Lavaud, J., Strzepek, R.F., \& Kroth, P.G. (2007). Photoprotection capacity differs among diatoms : Possible consequences on the spatial distribution of diatoms related to fluctuations in the underwater light climate. Limnology and Oceanography, 52: 1188-1194.

Laviale, M., Barnett, A., Ezequiel, J., Lepetit, B., Frankenbach, S., Méléder, V., Serôdio, J. \& Lavaud, J. (2015). Response of intertidal benthic microalgal biofilms to a coupled light-temperature stress: evidence for latitudinal adaptation along the Atlantic coast of Southern Europe. Environmental Microbiology, 17: 3662-3677. 
Laviale, M., Frankenbach, S. \& Serôdio, J. (2016). The importance of being fast: comparative kinetics of vertical migration and non-photochemical quenching of benthic diatoms under light stress. Marine Biology, 163: 10.

van Leeuwe, M., Brotas, V., Consalvey, M., Forster, R., Gillespie, D., Jesus, B., Roggeveld, J. \& Gieskes, W. (2008). Photoacclimation in microphytobenthos and the role of xanthophyll pigments. European Journal of Phycology, 43: 123-132.

Litchman, E., \& Klausmeier, C.A. (2008). Trait-Based Community Ecology of Phytoplankton. Annual Review of Ecology, Evolution, and Systematics, 39: 615639.

Miller, A.R., Lowe, R.L. \& Rotenberry, J.T. (1987). Succession of Diatom Communities on Sand Grains. The Journal of Ecology, 75: 693-709.

Olaizola, M. \& Yamamoto, H.Y. (1994). Short-term response of the diadinoxanthin cycle and fluorescence yield to high irradiance in Chaetoceros muelleri (Bacillariophyceae). Journal of Phycology, 30: 606-612.

Perkins, R.G., Kromkamp, J.C., Serôdio, J., Lavaud, J., Jesus, B., Mouget, J.L., Lefebvre, S. \& Forster, R.M. (2010a). In Chlorophyll a Fluorescence in Aquatic Sciences: Methods and Applications (Suggett, D.J., Prášil, O. \& Borowitzka, M.A., editors), 237-275. Springer, Netherlands.

Perkins, R.G., J. Lavaud, J. Serôdio, Mouget, J.L., Cartaxana, P., Rosa, P., Barille, L., Brotas, V. \& Jesus, B. (2010b). Vertical cell movement is a primary response of intertidal benthic biofilms to increasing light dose. Marine Ecology Progress Series, 416: 93-103. 
556 Pniewski, F.F., Biskup, P., Bubak, I., Richard, P., Latała, A. \& Blanchard, G. (2015).

557 Photo-regulation in microphytobenthos from intertidal mudflats and non-tidal

558 coastal shallows. Estuarine, Coastal and Shelf Science, 152: 153-161.

559 Raven, J.A. (2011). The cost of photoinhibition. Physiologia Plantarum, 142: 87-104.

560 Ribeiro, L., Brotas, V., Rincé, Y. \& Jesus, B. (2013). Structure and diversity of

561 intertidal benthic diatom assemblages in contrasting shores: a case study from the

562 Tagus estuary. Journal of Phycology, 49: 258-270.

563 Round, F.E., Crawford, R.M. \& Mann, D.G. (1990). The Diatoms - Biology \&

564 Morphology of the genera. Cambridge University Press.

565 Rouse, J.W., Jr, Haas, R.H., Schell, J.A. \& Deering, D.W. (1974). Monitoring

566 Vegetation Systems in the Great Plains with Erts. In Third Earth Resources

567 Technology Satellite-1 Symposium- Volume I: Technical Presentations (Freden,

568 S.C., Mercanti, E.P. \& Becker, M. A., editors), 309-317. NASA, Washington,

$569 \quad$ D.C.

570 Sabbe, K. (1993). Short-term fluctuations in benthic diatom numbers on an intertidal

571 sandflat in the Westerschelde estuary (Zeeland, The Netherlands). Hydrobiologia,

$572 \quad 269: 275-284$.

573 Sabbe, K., Witkowski, A. \& Vyverman, W. (1995). Taxonomy, Morphology and

574 Ecology of Biremis lucens comb. nov. (Bacillariophyta): A brackish-marine,

575 benthic diatom species comprising different morphological types. Botanica

$576 \quad$ Marina, 38: 379-391.

577 Sabbe, K. (1997). Systematics and ecology of intertidal benthic diatoms of the 
Serôdio, J., Cruz, S., Vieira, S. \& Brotas, V. (2005). Non-photochemical quenching of chlorophyll fluorescence and operation of the xanthophyll cycle in estuarine microphytobenthos. Journal of Experimental Marine Biology and Ecology, 326: $157-169$.

Serôdio, J., Ezequiel, J., Barnett, A., Mouget, J.L., Méléder, V, Laviale, M. \& Lavaud. J. (2012). Efficiency of photoprotection in microphytobenthos: role of vertical migration and the xanthophyll cycle against photoinhibition. Aquatic Microbial Ecology, 67: 161-175.

Serôdio, J., Marques da Silva, J. \& Catarino, F. (2001). Use of in vivo chlorophyll a fluorescence to quantify short-term variations in the productive biomass of intertidal microphytobenthos. Marine Ecology Progress Series, 218: 45-61.

Serôdio, J., Vieira, S. \& Cruz, S. (2008). Photosynthetic activity, photoprotection and photoinhibition in intertidal microphytobenthos as studied in situ using variable chlorophyll fluorescence. Continental Shelf Research, 28: 1363-1375.

Serôdio, J., Vieira, S., Cruz, S. \& Coelho, H. (2006). Rapid light-response curves of chlorophyll fluorescence in microalgae: relationship to steady-state light curves and non-photochemical quenching in benthic diatom-dominated assemblages. Photosynthesis research, 90: 29-43.

Underwood, G.J.C., Perkins, R.G., Consalvey, M.C., Hanlon, A.R.M., Oxborough, K. , Baker, N.R. \& Paterson, D.M. (2005). Patterns in microphytobenthic primary productivity: Species-specific variation in migratory rhythms and photosynthesis in 

mixed-species biofilms. Limnology and Oceanography, 50: 755-767.

Zhu, S., Guo, J., Maldonado, M. T. \& Green, B. R. (2010). Effects of iron and copper deficiency on the expression of members of the light-harvesting family in the diatom Thalassiosira pseudonana (Bacillariophyceae). Journal of Phycology, 46: 974-981.

\section{Figures legends}

\section{Fig. 1}

Fig. 1: Light microscopy photographs of the species used in this study. a: Navicula arenaria var. rostellata, b: Craspedostauros britannicus, c: Seminavis robusta, d: Entomoneis paludosa, e: Navicula phyllepta, f: Planothidium delicatulum, g: Biremis lucens, h: Nitzschia cf. frustulum, i: Opephora guenter-grassii. Scale bar $=10 \mu \mathrm{m}$.

\section{Fig. 2}

Fig. 2: A schematic overview of artificial biofilm preparation.

\section{Fig. 3}

Fig. 3: The linear regression of the Normalized Difference Vegetation Index (NDVI) with chlorophyll a content, determined spectrophotometrically, on a Phaeodactylum tricornutum dilution series centrifuged on kaolin.

\section{Fig. 4a, b, c, d}

Fig. 4a, b, c, d: The decrease in surface biomass, measured as NDVI, of epipelic diatoms (a) and epipsammic diatoms (b) on kaolin during 30 min of HL. Note that the $\mathrm{y}$-axis in these plots starts at 50\%. Non-photochemical quenching (NPQ) for epipelic 
623 diatoms (d) and epipsammic diatoms (c), measured during $30 \mathrm{~min}$ HL and $30 \mathrm{~min}$ LL

624 recovery. Values represent averages of three independent measurements \pm standard

625 deviations.

\section{Fig. 5}

627 Fig. 5: The quantum yield of PSII ( $\Delta \mathrm{F} / \mathrm{Fm}$ '), after $30 \mathrm{~min}$ of HL and $30 \mathrm{~min}$ of LL

628 recovery, expressed in percentage of the maximal photosynthetic efficiency of PSII

$629\left(\mathrm{~F}_{\mathrm{v}} / \mathrm{F}_{\mathrm{m}}\right)$ before HL exposure for epipelic (black bars) and epipsammic diatoms (white

630 bars). Values represent averages of three independent measurements \pm standard

631 deviations.

632

633 Fig. 6

634 Fig. 6: The extent of vertical migration (measured as the decrease in surface biomass in 635 percentage, cf. Fig. 4a, b), measured after $30 \mathrm{~min}$ of HL in function of the NPQ capacity, 636 measured after 5 min of HL to avoid the effect of photoinhibition for epipelic (black 637 symbols) and epipsammic diatoms (white symbols). Three replicates per species are 638 plotted (with exception of E. paludosa, $\mathrm{n}=2$ ). 


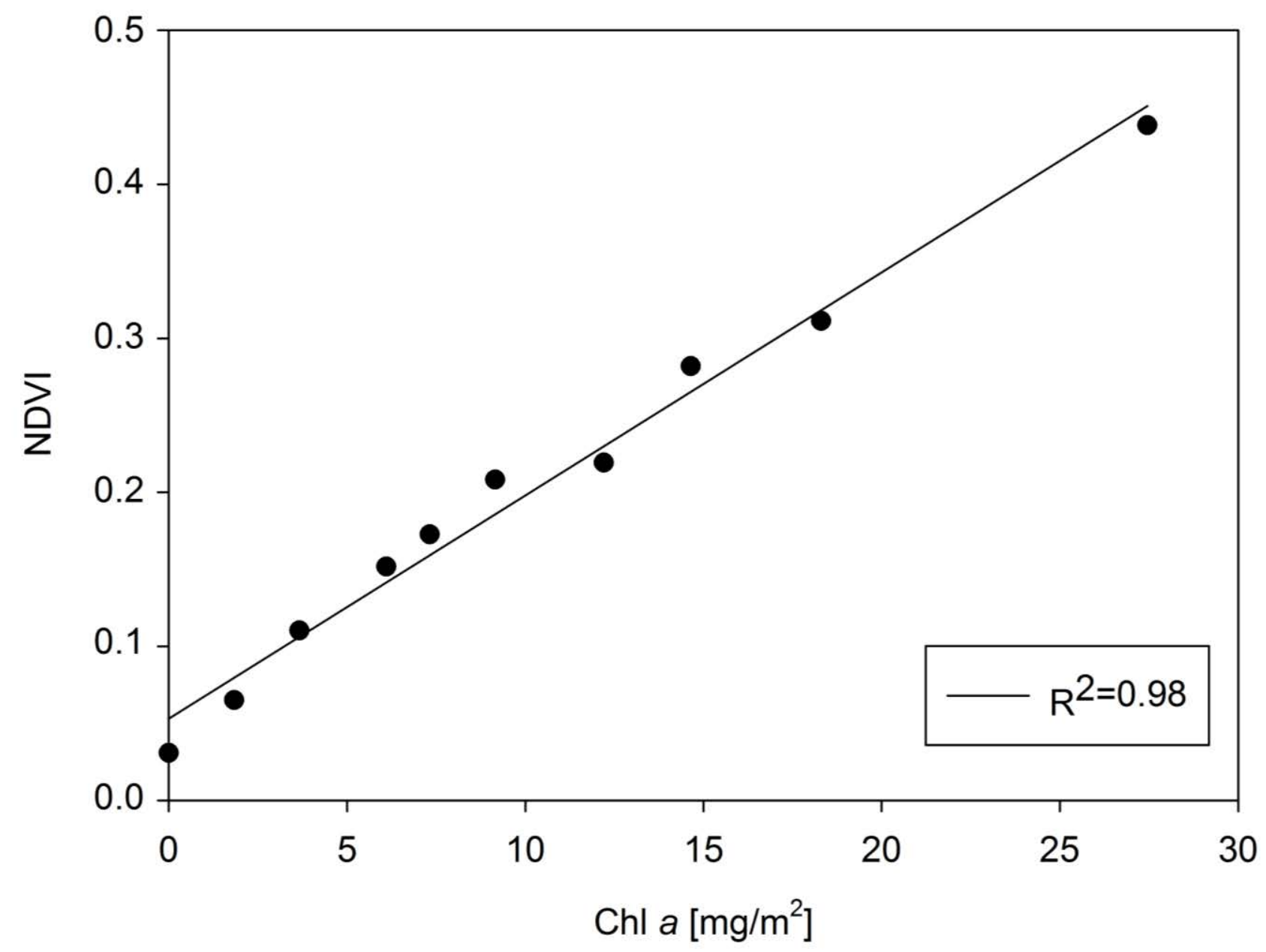


a Epipelic diatoms
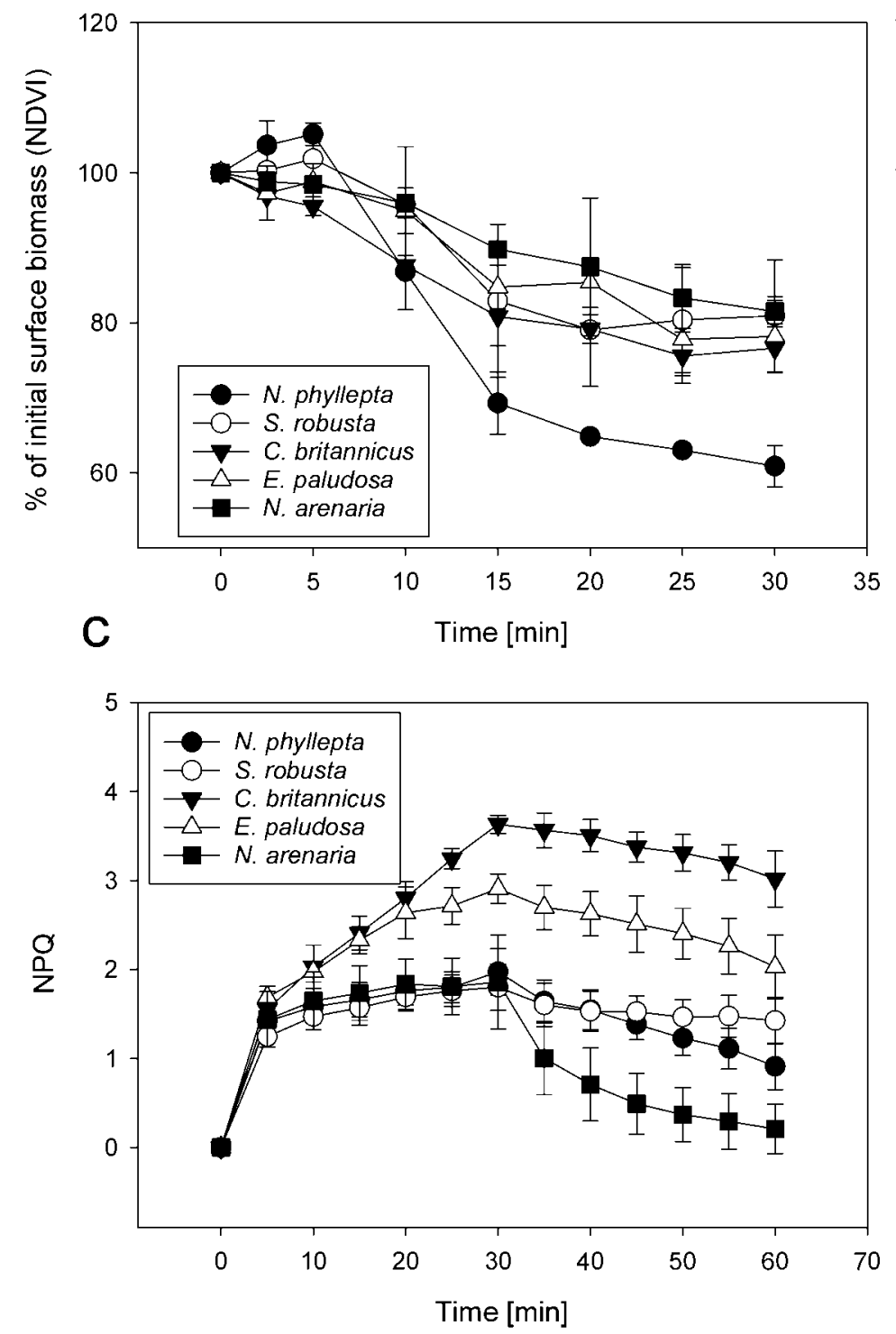

b Epipsammic diatoms
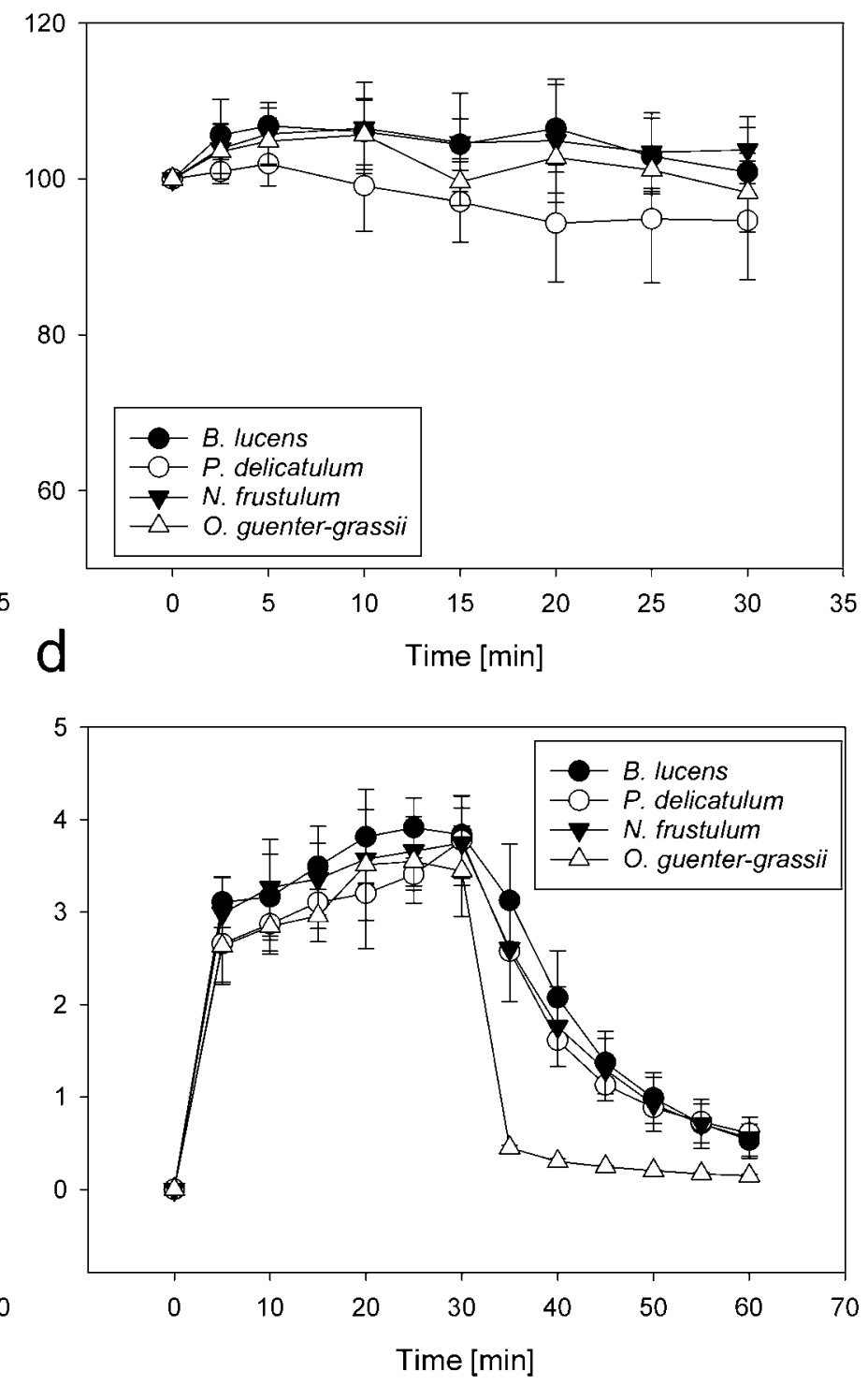


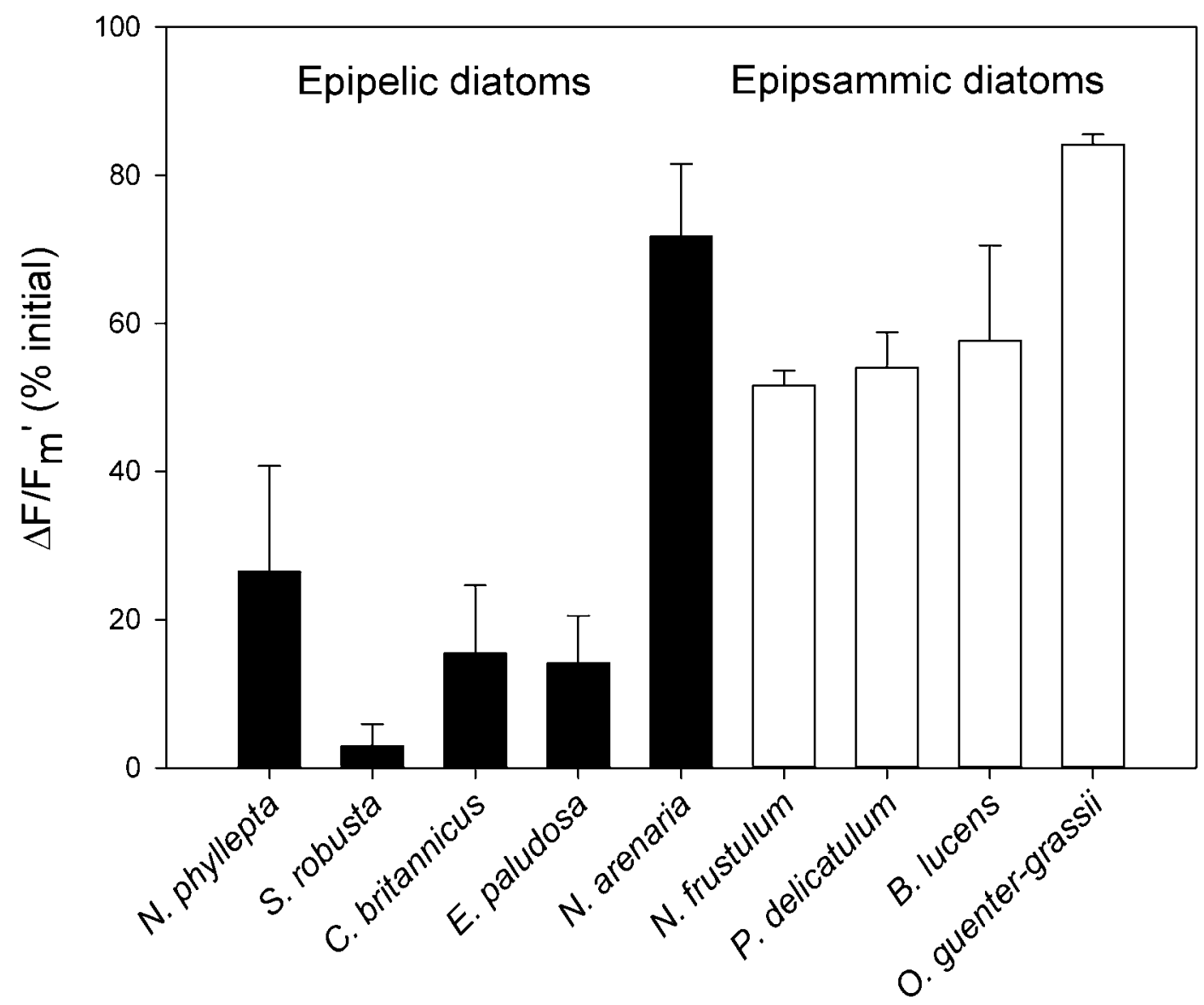




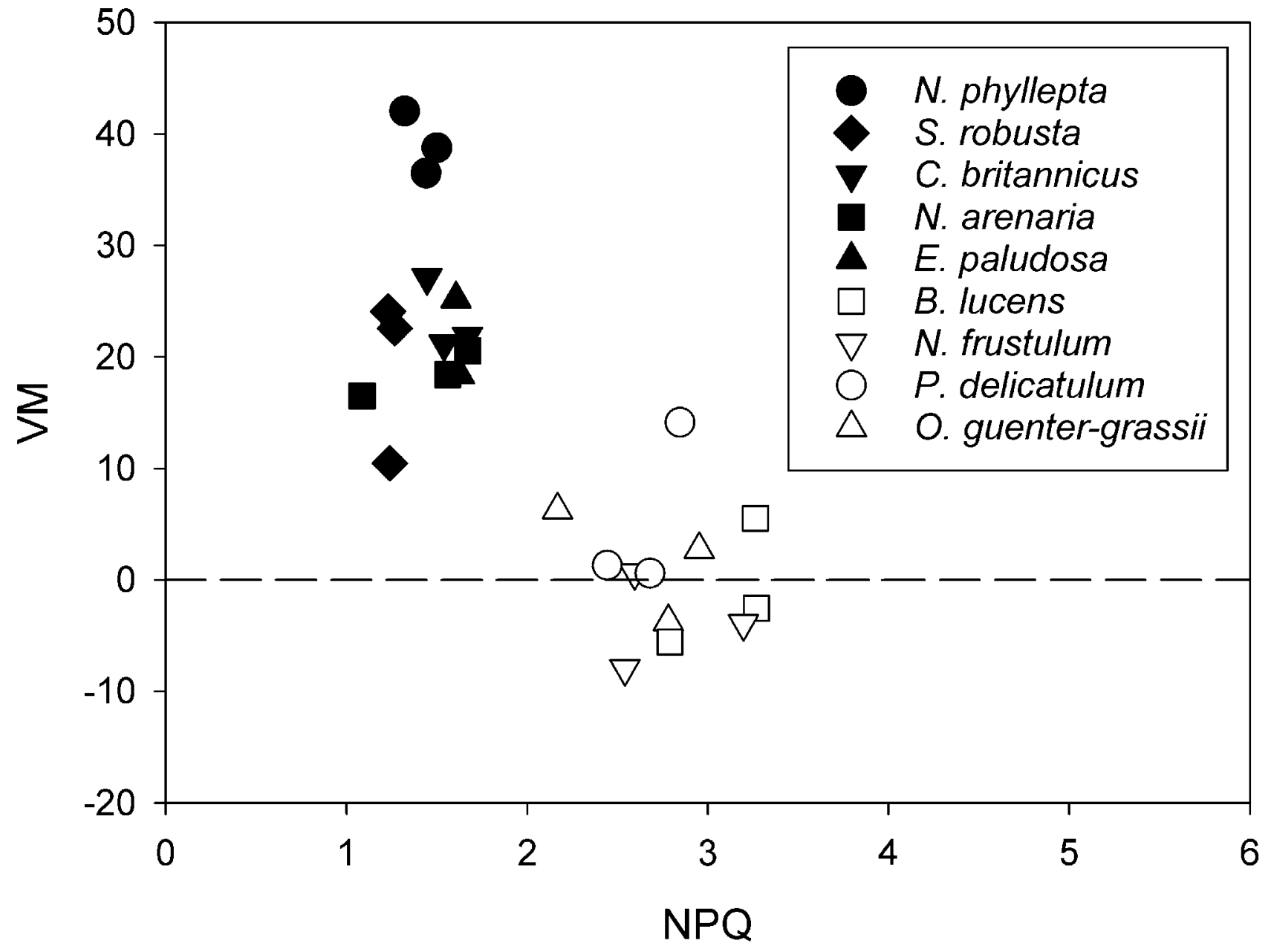

